\title{
TINJAUAN TEOLOGIS TERHADAP \\ BUDAYA PEMANGGILAN ARWAH ORANG MATI PADA SUKU PAMONA
}

\author{
Jusman Tago'a \\ I Ktut Enoh \\ Sttjaffray@yahoo.com
}

\section{PENDAHULUAN}

\section{Latar Belakang Masalah}

Dalam sepanjang sejarah gereja, gereja selalu diperhadapkan kepada berbagai tantangan dan halangan untuk membina jemaatnya menjadi jemaat yang benar-benar menjadi orang Kristen yang sejati, orang Kristen yang hanya percaya kepada Yesus Kristus sebagai satusatunya Tuhan dan juruselamat serta sumber pertolongan bagi mereka. Khususnya di Indonesia, budaya masing-masing suku di tiap-tiap daerah dan tidak jarang budaya budaya yang dimiliki oleh tiap-tiap daerah itu bertentangan dengan Firman Tuhan. Hal ini tentunya merupakan tantangan yang tidak dapat disangkali dan merupakan tantangan yang berat dan perlu disikapi dengan serius oleh gereja Tuhan. Apalagi jika budaya itu adalah budaya yang telah berlangsung turun temurun dari sejak zaman nenek moyang mereka dan dijalankan oleh generasi ke generasi, maka tentunya budaya itu memiliki ikatan yang sangat kuat dengan suku yang melakukan budaya itu. Hal ini tentu pula bukanlah hal yang mudah bagi gereja Tuhan untuk menyelesaikannya.

Dari sekian banyak suku dan budaya yang ada di Indonesia, salah satunya adalah suku Pamona yang mulanya berasal dari daerah Kabupaten Poso, Provinsi Sulawesi Tengah. Namun dalam perkembangannya dari sejak ratusan tahun lalu telah menyebar sampai ke Kabupaten Luwu, sekarang menjadi Kabupaten Luwu Timur Propinsi Sulawesi Selatan. Sebagai suku yang besar, suku Pamona juga tentunya memiliki banyak budaya yang mereka warisi dari nenek moyang mereka yang sampai hari ini masih mereka laksanakan dalam kehidupan mereka. Yang menjadi persoalan adalah banyak dari budaya itu yang bertentangan dengan Firman Tuhan padahal mereka sudah menjadi orang Kristen sudah lama pula. Salah satu dari sekian banyak budaya itu adalah budaya pemanggilan arwah orang mati, yang biasanya dilakukan pada malam hari yakni malam ketiga ketika salah satu keluarga dari orang Pamona meninggal dunia. Pada suku Pamona budaya ini dikenal dengan istilah "mompikasi" yang artinya "memadamkan" atau "menggelapkan". Ketika salah satu keluarga dari suku Pamona meninggal, maka pada malam ketiga semua keluarga akan berkumpul di rumah orang yang meninggal itu, kemudian melalui seorang tua-tua kampung yang memang memiliki kemampuan khusus untuk berkomunikasi dengan arwah orang mati, orang inilah yang akan memanggil arwah orang mati itu. Dalam keyakinan orang Pamona tujuan utama "mompikasi" ini adalah untuk memanggil arwah keluarga mereka yang telah meninggal itu untuk datang mengunjungi rumahnya untuk yang terakhir kali dan mengambil barangbarang kesayangannya semasa dia hidup yang mungkin saja keluarganya lupa masukkan ke dalam peti jenazah orang yang telah meninggal itu.

Sungguh tragis, suku Pamona di Desa Maleku, Kecamatan Mangkutana ini hampir 100 persen adalah pemeluk agama Kristen sudah sejak lama, mereka rajin ke gereja dan mengikuti kegiatan-kegiatan kerohanian lainnya, namun sayang banyak dari mereka yang masih hidup dengan cara yang tidak sesuai dengan Firman Tuhan, banyak diantara mereka yang masih melakukan budaya pemanggilan arwah ini padahal jelas-jelas itu bertentangan dengan Firman Tuhan.

Bagi penulis, gereja tidak boleh tinggal diam, gereja harus memiliki sikap yang jelas dan tegas agar orang-orang Pamona yang telah menjadi Kristen ini memiliki pemahaman yang benar tentang iman Kristen, agar mereka dapat bertumbuh menjadi orang Kristen yang dewasa dan memuliakan Tuhan serta tidak melakukan praktek-praktek budaya yang tidak sesuai dengan Alkitab. Untuk itulah penulis sangat tertarik untuk membahas hal ini dalam sebuah karya ilmiah dengan judul: 


\section{Pokok Masalah}

Berdasarkan latar belakang masalah, maka rumusan pokok masalah dalam penulisan ini adalah bagaimana pandangan Alkitab tentang pemanggilan arwah orang mati pada suku Pamona? Serta bagaimana peran gereja dalam menjelaskan kepada suku Pamona bahwa budaya pemanggilan arwah orang mati pada suku Pamona adalah budaya yang bertentangan dengan Alkitab?

\section{Tujuan Penulisan}

Adapun tujuan penulis melakukan penulisan ini ialah:

Pertama, sebagai orang Pamona penulis hendak menambah wawasan pengetahuan serta memperdalam pemahaman tentang ragam yang ada pada Suku Pamona, secara khusus budaya pemanggilan arwah (mompikasi) yang pada suku Pamona dikenal dengan istilah "mompikasi". juga untuk menambah wawasan bagi para pembaca tulisan ini.

Kedua, untuk menjelaskan kepada orang-orang Pamona yang telah menjadi pemeluk agama Kristen, bahwa budaya pemanggilan arwah itu harus segera di tinggalkan karena budaya itu adalah dosa dihadapan Tuhan dan tidak sesuai dengan Firman Tuhan.

Ketiga, untuk memberi motivasi kepada para rekan-rekan hamba Tuhan khususnya bagi hamba-hamba Tuhan yang melayani di suku-suku Pamona untuk lebih tegas dan berani dalam menyampaikan Firman Tuhan kepada jemaat yang dilayani.

Keempat, untuk memenuhi persyaratan bagi penulis dalam rangka menyelesaikan program sarjana di Sekolah Tinggi Teologi Jaffray Makassar.

\section{Batasan Penulisan}

Dalam budaya suku Pamona sebenarnya terdapat beberapa hal yang sehubungan dengan kepercayaan terhadap arwah orang mati. Namun pada penulisan ini penulis lebih memfokuskan pada satu budaya saja, yakni tentang budaya pemanggilan arwah pada suku Pamona yang berada di Desa Maleku, Kecamatan Mangkutana, Kabupaten Luwu Timur.

\section{METODOLOGI PENELITIAN}

\section{Budaya Pemanggilan Arwah Orang Mati Dalam Kepercayaan Suku Pamona Di Desa Maleku}

\section{Pengertian Budaya Secara Umum}

Menurut Kamus

Pertama. Menurut Kamus Besar Bahasa Indonesia. Kebudayaan adalah: 1. Hasil kegiatan dan penciptaan batin (akal budi) manusia, seperti kepercayaan, kesenian dan adat istiadat. 2. Kebudayaan adalah antara keseluruhan pengetahuan manusia sebagai mahluk sosial yang digunakan untuk memahami lingkungan serta pengalamannya dan yang menjadi pedoman tingkah lakunya. ${ }^{1}$

Kedua. Menurut Kamus Umum Bahasa Indonesia. Kebudayaan adalah: 1. Segala sesuatu yang dilakukan oleh manusia sebagai hasil pemikiran dan akal budinya. 2. Peradaban sebagai hasil akal budi manusia. 3. Ilmu pengetahuan manusia sebagai mahluk sosial yang dimanfaatkan untuk kehidupannya dan memberikan manfaat kepadanya. ${ }^{2}$

Ketiga. Menurut Kamus Wikipedia Ensiklopedia Bebas Berbahasa Indonesia. Kebudayaan adalah sesuatu yang akan mempengaruhi tingkat pengetahuan dan meliputi sistem ide atau gagasan yang terdapat dalam pikiran manusia, sehingga dalam kehidupan sehari-hari, kebudayaan itu bersifat abstrak. ${ }^{3}$

Menurut Para Ahli

Pertama. Menurut Edward B. Taylor, Kebudayaan merupakan keseluruhan yang kompleks, yang didalamnya terkandung pengetahuan, kepercayaan, kesenian, moral, hukum, adat istiadat, dan kemampuan-kemampuan lain yang didapat oleh seseorang sebagai anggota masyarakat. ${ }^{4}$

\footnotetext{
${ }^{1}$ Tim Penyusun Kamus Pusat Pembinaan dan Pengembangan Budaya, Kamus Besar Bahasa Indonesia. (Jakarta: Balai Pustaka, 2001), 170

${ }^{2}$ J.S. Badudu dan Sutan Mohammad Zain, Kamus Umum Bahasa Indonesia. (Jakarta: Pustaka Sinar Harapan, 1994), 211

${ }^{3}$ Wikipedia Indonesia: Ensiklopedia Bebas Berbahasa Indonesia. s.v. "Kebudayaan”, diakses 16 April 2010; tersedia di http://id.wikipedia.org/wiki/Kebudayaan.

4 “ Definisi Kebudayaan”, Exalute.com; diakses tanggal 16 April 2010; tersedia di http://exalute.wordpress.com/2009/03/29/definisi-kebudayaan-menurut-para-ahli/. htm
} 
Kedua. Menurut Koentjaraningrat, Kebudayaan adalah keseluruhan sistem gagasan, tindakan, dan hasil karya manusia dalam rangka kehidupan masyarakat yang dijadikan milik diri manusia dengan belajar. ${ }^{5}$

Ketiga. Menurut William H. Haviland, Kebudayaan adalah seperangkat peraturan dan norma yang dimiliki bersama oleh para anggota masyarakat, yang jika dilaksanakan oleh para anggotanya akan melahirkan perilaku yang dipandang layak dan dapat di terima ole semua masyarakat. ${ }^{6}$

Keempat. Menurut Ki Hajar Dewantara, Kebudayaan berarti buah budi manusia adalah hasil perjuangan manusia terhadap dua pengaruh kuat, yakni zaman dan alam yang merupakan bukti kejayaan hidup manusia untuk mengatasi berbagai rintangan dan kesukaran di dalam hidup dan penghidupannya guna mencapai keselamatan dan kebahagiaan yang pada lahirnya bersifat tertib dan damai. ${ }^{Y}$

Kelima. Menurut Arkeolog R. Seokmono, Kebudayaan adalah seluruh hasil usaha manusia, baik berupa benda ataupun hanya berupa buah pikiran dan dalam penghidupan. ${ }^{8}$

Dari berbagai definisi di atas, dapat diperoleh kesimpulan mengenai kebudayaan yaitu sistem pengetahuan yang meliputi sistem ide gagasan yang terdapat di dalam pikiran manusia, sehingga dalam kehidupan sehari-hari kebudayaan itu bersifat abstrak. Sedangkan perwujudan kebudayaan adalah benda-benda yang diciptakan oleh manusia sebagai makhluk yang berbudaya, berupa perilaku dan benda-benda yang bersifat nyata, misalnya pola-pola perilaku, bahasa, peralatan hidup, organisasi sosial, religi seni dan lain-lain, yang kesemuanya ditujukan untuk membantu manusia dalam melangsungkan kehidupan bermasyarakat.

\section{Pemanggilan Arwah Atau Mompikasi Pada Suku Pamona}

\section{Definisi}

Menurut Sarri Tago'a yang adalah nara sumber utama dari tulisan ini, Mompikasi berarti menggelapkan atau memadamkan lampu. Karena upacara ini hanya bisa dilaksanakan pada malam hari sehingga di sebut mompikasi. Orang-orang Pamona meyakini bahwa arwah keluarga mereka yang telah meninggal itu akan segera datang jika lampu telah dipadamkan. ${ }^{9}$

\section{Maksud dan Tujuan}

Adapun maksud dan tujuan pemanggilan arwah:

Pertama. Untuk memberi kesempatan kepada arwah yang telah meninggal itu untuk datang kerumahnya dan mengambil barang-barang kepunyaannya semasa dia masih hidup yang lupa dimasukkan oleh keluarganya ke dalam peti jenazah ketika dia di kuburkan.

Kedua. Jika ada salah satu keluarga yang ingin melihat arwah orang yang telah meninggal itu, biasanya ini adalah permintaan khusus dari suami/istri/orang tua atau anak dari yang telah meninggal itu kepada orang yang biasa memimpin upacara ini.

Ketiga. Untuk datang memberi pesan terakhir kepada keluarga yang telah ditinggalkannya. Biasanya pesan ini disampaikan melalui Mokole (pemimpin upacara) yang memimpin upacara ini.

Keempat. sebagai wujud rasa sayang dan hormat kepada suami/istri/orang tua atau anak yang yang telah meninggal itu.

\section{Tempat Dan Waktu Pelaksaan}

Upacara pemanggilan arwah ini hanya bisa dilaksanakan di rumah orang yang telah meninggal itu dan tidak bisa dilaksanakan di tempat lain dengan alasan apapun. Hal ini dimaksudkan karena jika dilaksanakan di tempat lain maka upacara mompikasi ini tidak akan berjalan dengan baik. Arwah yang dipanggil itu pasti tidak akan datang tetapi bisa saja setan-setan yang jahat yang akan datang dan membahayakan orang-orang yang ada dalam pelaksaan upacara ini.

Upacara Mompikasi dilakukan pada malam hari, sekitar Pukul 19.00-20.00 Wita. Karena menurut kepercayaan mereka waktu-waktu itulah yang paling baik dan arwah yang dipanggil itu pasti akan datang. Sementara durasi waktu yang dibutuhkan untuk

\footnotetext{
${ }^{5}$ Ibid.

${ }^{6}$ Ibid.

${ }^{7}$ Ibid.

${ }^{8}$ Ibid.

${ }^{9}$ Sarii Tago'a, Wawancara Oleh Penulis. Mangkutana, 6 April 2010
} 
pelaksanaan upacara mompikasi ini adalah sekitar 15-20 menit saja. Tidak boleh terlalu lama karena mereka meyakini jika terlalu lama maka arwah-arwah yang jahat yang menemani arwah kelaurga mereka yang datang itu akan berlaku jahat terhadap orang-orang yang ada pada saat pelaksanaan upacara itu. ${ }^{10}$

\section{Persiapan Pada Saat Upacara Mompikasi}

Agar pelaksanaan upacara mompikasi ini berjalan dengan lancar, maka ada beberapa hal yang perlu dipersiapkan:

Pertama. Makanan dan minuman yang diletakkan di meja makan atau di kamar pribadi dari orang yang telah meninggal itu. Mereka meyakini bahwa ketika arwah itu datang dari kuburannya yang jauh, pastilah dia merasa lelah dan lapar dan ketika dia datang maka dia akan makan dan minum apa yang telah disiapkan oleh keluarganya.

Kedua. Lampu pelita. Ketika pemimpin upacara ini memberi komando atau aba-aba agar semua lampu di rumah itu dipadamkan, maka ada seseorang yang ditugaskan khusus untuk bersiap-siap untuk menyalakan lampu pelita itu dan jika sampai terlambat maka arwah-arwah yang jahat akan segera masuk dan bisa mencelakakan orang-orang yang ada dalam rumah itu.

Ketiga. Abu Dapur dan Benang Hitam. Abu dapur diletakkan di pintu depan dan pintu belakang rumah, demikian juga dengan benang hitam, di ikatkan di pintu depan dan pintu belakang rumah. Hal ini dimaksudkan untuk membuktikan bahwa arwah keluarga mereka itu benar-benar telah datang dan tandanya adalah benang itu akan putus dan akan ada tanda telapak kaki pada abu dapur yang diletakkan di pintu depan atau belakang rumah. ${ }^{11}$

\section{Pelaksana Upacara pemanggilan arwah}

Upacara mompikasi ini bukanlah hal yang mudah dan tidak bisa dilaksanakan oleh sembarang orang, untuk itu ada beberapa pihak yang harus terlibat agar upacara ini bisa berjalan dengan baik:

Pertama. Pihak keluarga, dalam upacara pemanggilan arwah ini harus dihadiri oleh semua kelurga dari orang yang telah meninggal itu, terlebih khusus keluarga terdekat seperti suami/istri/kakak/adik/orang tua atau anak. Jika tidak, maka arwah orang yang telah meninggal itu tidak akan datang.

Kedua. Salah satu tua kampung, dia bertugas untuk menyalakan lampu pelita yang telah dipersiapkan. Ini bukanlah hal yang mudah, dibutuhkan keberanian khusus, karena lampu pelita tadi harus ditempatkan di dekat pintu masuk rumah. Dialah yang bertugas untuk menyalakan lampu ketika pemimpin upacara ini memberikan perintah untuk segera meyalakan lampu.

Ketiga. Pemimpin Upacara. Pemimpin upacara di sebut Mokole atau pembesar atau ketua adat. Namun tidak semua ketua adat pada suku Pamona bisa memimpin upacara pemanggilan arwah ini. Menurut Sarii Tago'a yang biasa menjadi pemimpin upacara ini, kemampuan untuk memimpin upacara ini tidak didapatkan melalui proses belajar atau di ajarkan oleh orang lain tetapi memang merupakan kemampuan yang bersifat turunan dan sampai hari ini hanya ada dua orang saja di seluruh Kabupaten Luwu Timur yang bisa memimpin upacara ini. Mokole bertugas untuk memanggil arwah orang mati itu, kemudian saat arwah orang mati itu datang dan masuk kedalam rumah, mokole ini bertugas untuk menjaga diluar rumah agar teman-teman arwah yang datang itu tidak ikut masuk kedalam rumah. Tugas lain dari Mokole ini adalah untuk berkomunikasi dengan arwah itu jika ada pesan khusus yang disampaikan oleh arwah itu kepada keluarganya. ${ }^{12}$

\section{P E M B A H A S A N}

\section{Kepercayaan Suku Pamona Kepada Arwah Orang Mati}

\section{Kemana Seseorang Yang Baru Saja Meninggal?}

Bagi suku Pamona, ketika seseorang meninggal maka orang yang meninggal itu tidak atau belum menyadari bahwa dirinya sebenarnya telah meninggal. Nanti setelah selama empat puluh hari empat puluh malam, barulah orang yang meninggal itu menyadari bahwa dirinya sudah meninggal dan dia sudah tidak lagi berada di dunia yang sama ketika dia masih hidup. Orang-orang Pamona meyakini bahwa selama empat puluh hari empat puluh malam

\footnotetext{
${ }^{10}$ Ibid.

11 Ibid.

12 Ibid.
} 
itu, orang yang meninggal dunia itu akan mengunjungi semua keluarga dan tempat yang pernah dia kunjungi selama dia hidup. Itulah sebabnya orang-orang Pamona yang masih mempercayai hal ini, ketika ada keluarga mereka meninggal dunia maka selama empat puluh hari empat puluh malam akan menyediakan makanan di sudut rumah mereka tiap pagi, siang dan malam, karena mereka menganggap bahwa keluarga mereka yang telah meniggal itu akan datang dan memakan makanan yang mereka telah siapkan itu. ${ }^{13}$

Orang-orang Pamona sangat takut dan menghargai orang-orang yang sudah meninggal. Mengapa? Sebab orang-orang Pamona meyakini bahwa orang yang sudah meninggal dapat memberikan berkat kepada keluarga yang masih hidup, orang yang sudah meninggal diyakini dapat menjaga mereka dari hal-hal yang jahat namun juga dapat mendatangkan malapetaka bagi keluarga yang masih hidup jika mereka tidak menghargai orang yang sudah meninggal itu. ${ }^{14}$

\section{Manifestasi Roh Orang Mati Pada Orang Pamona}

Menurut John A MacMillan, "Perjanjian Lama memperkenalkan kepada kita serbaneka ilah. Kita mendapati bahwa manusia sejak awal zaman memuja dewa-dewanya dan menyerahkan diri dalam berbagai metode penyembahan. Filsafat-filsafat yang mendasari bentuk-bentuk penyembahan ini kadangkala mulia dan agung secara teori, namun dalam prakteknya cenderung menjadi amat keji. ${ }^{9}$

Hampir disemua daerah dan suku-suku yang berada di Indonesia bahkan di dunia ini memiliki kepercayaan kepada roh-roh orang mati dan biasanya setiap daerah meyakini ada bentuk-bentuk dan rupa-rupa manifestasi yang digunakan oleh Iblis untuk menampakkan dirinya dan membuat manusia yakin bahwa apa yang diyakini oleh manusia itu adalah sesuatu yang benar-benar nyata.

Menurut E.P. Gintings, Djorelit Surbakti dan Maria Br. Ginting

Iblis adalah musuh semua yang baik, penuh penipuan dan kejahatan yang terus berusaha merusakkan anak Allah yang baik dan benar (Kis. 13:10). Oleh sebab itu, Iblis dinamai sebagai "bapa pembohong" ia tidak berdiri pada yang benar karena memang tidak ada kebenaran padanya. ${ }^{16}$

Dalam buku yang di tulis oleh Institut Teologia Gereja Toraja mengatakan, "Banyak macam roh-roh jahat yang berasal dari kepercayaan akan jiwa orang mati. Roh-roh demonis dipandang sebagai roh yang mengerikan sebab dapat membinasakan. Ia tidak dapat dipercaya karena kadangkala bertindak sewenang-wenang. Manusia sangat menakutinya sehingga ketakutan ini sangat mempengaruhi kehidupannya". ${ }^{17}$

Demikian pula dalam kepercayaan suku Pamona yang berada di Desa Maleku, Kecamatan Mangkutana, mereka meyakini ada beberapa bentuk penampakan atau manifestasi arwah orang mati yang biasa mereka lihat dan alami dalam kehidupan mereka sehari-hari, diantaranya:

\section{Bulinde}

Bulinde artinya setan yang berjalan tanpa kepala. Orang Pamona meyakini bahwa sampai hari ini masih ada roh-roh nenek moyang mereka yang dulunya meninggal karena di penggal mati oleh gerombolan atau yang di penggal pada zaman penjajahan Belanda dan Jepang. Jika orang-orang Pamona berjalan di dalam hutan dan mereka mengucapkan katakata yang tidak sopan, maka diyakini setan Bulinde inilah yang akan mendatangi orang yang mengucapkan kata-kata kotor itu. ${ }^{18}$

\section{Renggeana}

"Rengge" artinya "mama” dan "ana” artinya "anak". Jika ada seorang ibu yang meninggal saat dia melahirkan, maka orang Pamona meyakini bahwa roh ibu itu akan menjadi renggeana. Rohnya akan bergentayangan pada malam hari dan akan mengganggu atau mengejar orang-orang yang sedang berjalan di malam hari. Renggeana adalah bentuk manifestasi setan yang sangat ditakuti oleh orang-orang Pamona, jika di sebuah kampung ada seorang ibu yang meninggal ketika dia melahirkan, maka jarang atau bahkan tidak ada orang yang berani keluar rumah pada malam hari.

\footnotetext{
${ }_{13}^{13}$ Pabindu, wawancara dengan penulis, Mangkutana, 5 April 2010

${ }^{14}$ Ibid

${ }^{15}$ John A. macMillan, Perjuangan Melawan Kuasa Kegelapan. (Malang: Gandum Mas), 24.

${ }^{16}$ Gintings E.P, Surbakti Djorelit. Dan Ginting Br. Maria, OKULTISME. (Bandung: Bintang Media Informasi, 2007), 21-22.

${ }_{17}^{17}$ Seri Institut Theologia Gereja Toraja-SITGT No. 1, 10.

${ }^{18}$ Sarri Tago'a, Wawancara oleh Penulis, Mangkutana, 6 April 2010.
} 


\begin{abstract}
Angga Nunu
Angga berarti setan dan Nunu berarti pohon besar. Jadi Angga Nunu berarti setan yang mendiami pohon besar. Tidak semua pohon besar memiliki atau didiami oleh setan, tetapi ada tanda-tanda khusus yang biasanya terdapat pada pohon itu untuk dapat mengetahui apakah pada pohon itu ada setan atau penunggunyanya atau tidak. Tanda-tanda itu antara lain adalah, pohon itu lebih besar dari antara pohon-pohon yang lain yang ada di sekitar tempat itu, batang pohon itu dililit oleh akar-akar pohon yang ada di sekitarnya, tanda lain yang biasanya dapat dilihat adalah jika ada orang yang mau menebang pohon itu, maka orang itu biasanya akan sakit bahkan bisa sampai meninggal dunia. Biasanya, jika pohon itu bisa di tebang maka akan mengeluarkan darah dan air. Suku Pamona meyakini bahwa darah itu adalah darah penunggu pohon itu dan air itu adalah air mata penunggu pohon itu.
\end{abstract}

\begin{abstract}
Angga Yopo
Yopo artinya hutan, jadi angga yopo berarti setan hutan. Orang-orang Pamona meyakini bahwa di setiap hutan dan gunung-gunung pasti terdapat banyak setan. Menurut mereka ada setan yang jahat dan membahayakan namun ada juga setan yang baik. Jika mereka berjumpa dengan setan yang baik maka mereka tidak perlu merasa takut, malahan setan itu biasanya akan membantu mereka untuk menemukan jalan jika mereka sedang tersesat di dalam hutan. Untuk membedakan setan yang jahat dan yang baik adalah, ketika orang-orang Pamona berjumpa dengan setan yang jahat, tanpa mereka berbuat apa-apa atau tanpa alasan apapun maka setan itu akan mengejar dan menyerang mereka. Tetapi jika mereka berjumpa dengan setan yang baik maka setan itu akan tersenyum dan biasanya akan menawarkan bantuan atau pertolongan.
\end{abstract}

\title{
Tumpu Tana
}

Tumpu berarti pemilik atau penguasa dan Tana berarti tanah atau wilayah. Jadi Tumpu Tana berarti pemilik atau penguasa tanah atau wilayah tertentu. Masyarakat suku Pamona meyakini bahwa setiap wilayah atau tempat, baik itu gunung, hutan, lahan persawahan, desa atau kampung, atau bahkan kota pasti dikuasai oleh satu kuasa kegelapan yang mereka yakini sebagai penjaga atau pelindung kawasan atau tempat itu. Jika mereka hendak melakukan sebuah kegiatan di suatu tempat, entah itu di sawah, di ladang, atau hendak membangun rumah baru, maka biasanya orang-orang Pamona memanggil dukun atau tua-tua kampung untuk berbicara kepada penguasa atau pemilik kawasan itu sebagai tanda permohonan isin dan maaf jika kehadiran atau aktifitas mereka ditempat itu mengganggu ketentraman penguasa kawasan atau wilayah itu.

\section{Bentuk-Bentuk Upacara Kematian Pada Suku Pamona Yorosinci}

Yorosinci berarti memutar cincin atau biasa juga di sebut hura-hura cincin. Permainan cincin ini di adakan di rumah orang yang telah meninggal dan hanya bisa dilakukan jika mayat masih ada di rumah itu. Biasanya permainan ini dilakukan dengan tujuan untuk menghibur keluarga yang sedang berduka, namun mengandung nilai-nilai magis. Dalam permainan cincin ini di iringi dengan menyanyikan lagu yang berisi pantun yang menceritakan sejarah atau perjalanan hidup yang dilewati oleh orang yang telah meninggal itu ketika dia masih hidup. Ketentuan yang harus dijalani adalah, ketika permainan ini sudah dimulai, maka tidak boleh berhenti sampai menjelang pagi, jika tidak, maka mereka meyakini bahwa semua yang ikut dalam permainan ini akan dihantui oleh arwah orang yang meninggal itu.

\section{Mompikasi}

Mompikasi berarti menggelapkan. Mengenai apa dan bagaimana upacara ini, penulis akan membahas lebih rinci pada pembahasan selanjutnya.

\section{Matampoli}

Matampoli atau biasa juga di sebut katesupa mata yang artinya terbaliknya mata. Maksudnya adalah, orang-orang Pamona meyakini bahwa pada hari ketiga ketika seseorang 
yang sudah meninggal itu dikuburkan, maka seluruh organ-organ tubuhnya akan mulai rusak dan itu dimulai dengan keluarnya bola mata mayat itu dari tubuhnya. Pada hari ketiga itu juga diyakini bahwa tubuh dari mayat orang mati itu telah mulai menyatu dengan tanah.

Upacara ini dilaksanakan di rumah keluarga yang meninggal dan harus dilaksanakan pada malam ketiga setelah meninggalnya keluarga mereka. Upacara ini dilaksanakan dengan maksud untuk mendoakan arwah keluarga yang telah meninggal itu agar tenang di alam sana dan tidak lagi memikirkan keluarga yang telah ditinggalkannya. Upacara ini dilaksanakan pada malam hari karena mereka menganggap malam hari adalah saat yang tepat agar arwah orang yang meninggal itu bisa datang dan mendengar doa-doa atau pesan-pesan yang disampaikan oleh keluarganya.

\section{Meloa}

Upacara meloa diadakan dengan maksud untuk memberi doa kepada orang mati, agar selama dalam perjalanannya menuju ke dunia mati, dapat selamat dan rohnya diterima oleh Puang Lamoa (Sang Pencipta), di samping sebagai tanda pernyataan cinta kasih dari sanak keluarga/isteri/suami yang telah ditinggalkan. Tujuan daripada upacara ini adalah agar keluarga yang masih hidup dapat sadar atas keberadaannya bahwa setiap orang yang masih hidup itu akan mengalami kematian, ini berarti bahwa suatu peringatan bagi orang-orang yang masih hidup, agar mereka dapat melakukan hal-hal yang baik saja dan menghindari hal-hal yang bertentangan menurut adat dan kepercayaan

Karena upacara ini merupakan rangkaian upacara-upacara sebelumnya dan juga sebagai upacara terakhir bagi orang-orang mati yang dilakukan oleh pihak keluarga, maka seluruh keluarga, sanak keluarga, baik dari pihak keluarga isteri maupun pihak keluarga suami turut terlibat dalam upacara ini, sebagai tanda cinta kasih yang harus diberikan kepada si mati, di mana dalam pelaksanaan upacara ini masing-masing berperan untuk terlaksananya upacara ini dengan baik. Upacara Meloa dilakukan pada sore hari sampai menjelang malam hari, karena menurut kepercayaan mereka waktu-waktu itulah yang paling baik, dan doa yang diberikan kepada orang mati dapat dikabulkan oleh Puang Lamoa, sedang waktu untuk berkunjung ke kuburan dimulai sehari sesudah penguburannya sampai pada hari ke tiga.

Upacara ini pada umumnya dilakukan di pekuburan yang telah ditentukan di mana orang mati dikuburkan. ${ }^{19}$

\section{Moparuru}

Moparuru artinya mengumpulkan tulang-tulang jasad keluarga yang telah meninggal dunia. Tujuan pelaksanaan adalah sebagai wujud penghargaan dan rasa sayang kepada keluarga yang sudah meninggal. Dilaksanakan setelah genap setahun meninggalnya anggota keluarga. Biasanya pada pelaksaan upacara ini, semua anggota keluarga dari yang meninggal akan berkumpul sekalipun mereka berada di tempat yang jauh. Mereka meyakini jika ada anggota keluarga yang tidak hadir maka akan mendatangkan malapetaka dalam hidupnya. Upacara ini dilaksanakan di gua atau tempat dimana keluarga yang meninggal itu di kuburkan.

\section{Pemanggilan Arwah Orang Mati Dalam Perspektif Alkitab}

\section{Kehidupan Setelah Kematian}

Sebelumnya telah dijelaskan, bahwa Suku Pamona meyakini bahwa setelah seseorang meninggal, orang meninggal itu tidaklah menyadari bahwa dia telah meninggal. Nanti setelah empat puluh hari empat puluh malam baru dia tahu dan sadar bahwa dirinya telah meninggal. Kalau demikian bagaimana dengan pandangan iman Kristen? Apa yang Alkitab katakan tentang keadaan setelah kematian?

Dalam bukunya tentang kehidupan setelah kematian, Raymond A Moody mengatakan "Alkitab adalah buku yang paling banyak dibaca dan dibicarakan yang menyangkut soal-soal sifat aspekn spiritual manusia dan kehidupan setelah kematian. Tapi secara keseluruhan,

\footnotetext{
19 "Meloa": Forum Poso Bersatu .com; diakses 16 April 2010; tersedia di http://posobersatu.blogspot.com/2008/09/meloa.html.
} 
Alkitab secara relatif tidak mengatakan banyak tentang kejadian yang berlangsung sewaktu kematian atau tentang sifat dunia setelah kematian. ${ }^{20}$

Menurut Billy Graham, "Dari Alkitab kita mengetahui bahwa di balik kematian ada kehidupan yang berkelimpahan bagi para pengikut Kristus. Mereka yang sudah menyambut kasih karunia-Nya dan yang sudah diselamatkan akan kelak berada bersama-sama dengan Yesus di Surga". ${ }^{21}$

Tidak dapat disangkali bahwa kematian adalah sesuatu yang sangat menakutkan bagi semua manusia dan tentunya hal itu adalah yang wajar. Itulah sebabnya manusia dengan segala upaya berusaha untuk mempertahankan agar tetap hidup di dunia ini. Menurut Gladys Hunt, "Kematian bisa merupakan kegelapan dan juga bisa merupakan suatu jalan terselubung yang menuju terang. Itulah sebanya Rasul Paulus dapat menulis dengan sangat yakin bahwa kita tidak perlu berdukacita sepeti orang-orang lain yang tidak mempunyai harapan (I Tesalonika 4:13) dan berkata bahwa apa yang kita lihat sekarang dalam cermin (adalah) suatu gambaran yang samar-samar saja (I Korintus 13:12). Ada banyak lagi yang akan kita lihat nanti. ${ }^{22}$

\section{Pemanggilan Arwah Dalam Perjanjian Lama}

Manusia selalu bertindak berdasarkan standar kebenaran yang telah berlaku dan disepakati bersama-sama secara tumurun, itulah sebabnya mengapa hukum adat sangat berperan penting dalam kehidupan masyarakat pada umumnya. Sekalipun standar kebenaran itu melanggar Firman Tuhan namun terus dijalani dalam kehidupan orang-orang yang telah menjadi Kristen dan percaya kepada Tuhan. Untuk itu kita perlu memahami apa sebenarnya yang Alkitab katakan secara khusus tentang pemanggilan arwah orang mati.

Menurut Ray Summers, "Perjanjian Lama memandang kematian sebagai peristiwa yang diliputi oleh suasana yang kelam dan menyeramkan. Di dalam Perjanjian Lama terdapat bagian-bagian yang mengakui adanya hidup sesudah mati. Namun hal seperti itu secara relatif tidaklah begitu banyak, dan pengharapan yang terkadung di dalamnya agak suram sifatnya". ${ }^{23}$

Ada kisah yang menarik yang diceritakan dalam Perjanjian Lama sehubungan dengan pemanggilan arwah orang mati, bagian itu terdapat dalam I Samuel 28:3-25. Berdasarkan kisah ini banyak orang yang mengira bahwa sebenarnya pemanggilan arwah dalam agama Kristen itu diperbolehkan dan sah-sah saja. Jika membaca kisah ini tanpa ketelitian, maka tentunya akan kita juga akan mengira bahwa arwah yang hadir dalam kisah itu betul-betul adalah arwah dari Samuel yang telah mati itu.

H. Soekahar dengan tegas mengatakan, "Bahwa yang menampakkan diri pada perempuan petenung di Endor itu adalah Iblis sendiri yang menyamar, menampakkan diri seperti Samuel dalam gerak-gerik. Tentang hal itu kita tidak usah heran karena Iblis dapat menyamar seperti malaikat terang (II Korintus 11:4). Dari Ayub 7:9-10; 14:10-12, kita mengetahui dengan jelas bahwa roh orang yang sudah mati tidak akan muncul lagi di bumi ini sampai langit hilang lenyap. Roh orang mati tidak mungkin berkeliaran di bumi ini, pun tidak mungkin menolong orang hidup di bumi ini atau mengganggunya. Kalau kita Nampak bayangan orang yang sudah mati, atau mendengar suara rintihan seperti suara orang yang sudah mati itu; kita harus waspada! Jangan menyembahnya, jangan memujanya sebab itu adalah Iblis yang menyamar. Disitu terjadi permainan Iblis. Tuhan menentang spiritisme dalam bentuk apapun (Imamat 19:31; Ulangan 18:10-13; Yesaya 8:19-20). ${ }^{24}$

Berdasarkan penjelasan dan uraian diatas, maka sangat jelas bahwa menurut Alkitab, secara khusus dalam Perjanjian Lama tidaklah membenarkan praktek-praktek pemanggilan arwah orang mati dengan alasan apapun. Perjanjian Lama tidak sedikitpun memberikan dasar yang benar untuk melakukan pemanggilan arwah orang mati.

\section{Pemanggilan Arwah Dalam Perjanjian Baru}

Di dalam Perjanjian Baru, perkembanagan doktrin kebangkitan orang mati itu mencapai puncaknya. Pada masa itu orang-orang percaya bahwa kehidupan tubuh sesudah mati nampaknya menurut mereka, Yesus adalah Yohanes pembaptis yang hidup kembali (Markus 6:16; Matius 14:2; Lukas 9:7). Padahal anggapan itu salah. Anggapan itu lebih sejalan dengan paham hidup kembali (resuscitation) atau penjelamaan jiwa ke dalam tubuh yang lain (transmigration). Kepercayaan yang nyata dan tepat mengenai kebangkitan orang mati

\footnotetext{
${ }^{20}$ Raymond A. Moody, JR., M.D, Hidup Sesudah Mati. (Jakarta: Gramedia, 1987), 138.

${ }^{21}$ Billy Graham, Menghadapi Kematian dan Kehidupan Sesudahnya. (Bandung: Lembaga Literatur Baptis, 2001), 41.

${ }^{22}$ Gladys Hunt, Pandangan Kristen Tentang Kematian. (Jakarta: BPK Gunung Mulia, 1987), 10.

${ }^{23}$ Ray Summers, Di Balik Kubur. (Bandung: Lembaga Literatur Baptis, 1994), 11

${ }^{24}$ H. Soekahar, Satanisme Dalam Pelayanan Pastoral. (Malang: Gandum Mas, 1986), 23.
} 
ialah yang diungkapkan oleh Marta, ketika saudaranya mati. Ia berkata, "Aku tahu bahwa ia akan bangkit pada waktu orang-orang bangkit pada akhir zaman” (Yohanes 11:24). ${ }^{25}$

Menurut Pondsius Takaliung, "Firman Allah membuka keadaan orang yang sudah mati. Alkitab adalha buku yang paling dibenci oleh Iblis, karena kedoknya ditelanjangi habis dalam Alkitab. Juga jalan keselamatan diterangkan dengan jelas dan sederhana. Keterlibatan dalam ocultisme, banyak disebabkan karena kita tidak mengerti keadaan orang mati, sebab banyak diantara kita yang menyangka bahwa orang hidup dapat menghubungi orang mati. ${ }^{26}$

Dalam buku yang sama Pondsius juga menjelaskan, "Kata "mati" dijumpai pertama kali dalam Kejadian 2:16. Manusia pertama akan mati kalau melanggar firman Allah, yaitu dengan makan buah yang dilarang oleh Tuhan. Tetapi pada waktu mereka makan, mereka tetap hidup, bahkan mencapai 390 tahun (Kej. 5:4). Apakah yang mati? Pertama kali mereka mengalami kematian rohani (band, Efe. 2:1), kemudian disusul dengan kematian jasmani (Kej. 5:4). Dalam Kej. 5, sebanyak 8 kali disebut kata "mati", tanpa mengungkapkan keadaan mereka yang mati. Walaupun demikian firman Allah membuka tentang keadaan orang mati sebelum Yesus disalib". ${ }^{27}$ Lebih lanjut menurut Pondsius, "Paulus menyebut tubuhnya sebagai kemah, tempat kediamannya yang akan dibongkar (2 Korintus 5:1), dan kalua ia meninggal maka ia akan meninggalkan kemah yang lama itu dan pergi kepada Tuhan (2 Korintus 5: 6-8). Itu berarti, bahwa apabila seseorang meninggal, maka jiwanya langsung masuk sorga. ${ }^{28}$

Dalam Lukas 16:19-31 bercerita tentang Lazarus yang miskin dan sorang yang kaya, lalu kemudian Lazarus dan orang kaya itu mati, Lazarus berada di pangkuan Abraham sedangkan orang kaya itu berada di alam maut yang penuh dengan penderitaan dan kesengsaraan. Secara khusus dalam ayat 22-26 dikisahkan: "Kemudian matilah orang miskin itu, lalu dibawa oleh malaikat-malaikat ke pangkuan Abraham. Orang kaya itu juga mati, lalu dikubur. Dan sementara ia menderita sengsara di alam maut ia memandang ke atas, dan dari jauh dilihatnya Abraham, dan Lazarus duduk di pangkuannya. Lalu ia berseru, katanya: Bapa Abraham, kasihanilah aku. Suruhlah Lazarus, supaya ia mencelupkan ujung jarinya ke dalam air dan menyejukkan lidahku, sebab aku sangat kesakitan dalam nyala api ini. Tetapi Abraham berkata: Anak, ingatlah, bahwa engkau telah menerima segala yang baik sewaktu hidupmu, sedangkan Lazarus segala yang buruk. Sekarang ia mendapat hiburan dan engkau sangat menderita. Selain dari pada itu di antara kami dan engkau terbentang jurang yang tak terseberangi, supaya mereka yang mau pergi dari sini kepadamu ataupun mereka yang mau datang dari situ kepada kami tidak dapat menyeberang". ${ }^{29}$

Dalam Alkitab Penuntun Hidup Berkelimpahan menjelaskan sehubungan dengan Lukas 16:19-31 ini, "kehidupan orang kaya itu dihabiskan dengan gaya hidup yang berpusat pada diri sendiri. Ia membuat pilihan yang salah dan menderita selama-lamanya (ayat 22-23). Seumur hidupnya Lazarus hidup dalam kemiskinan, namun hatinya benar dihadapan Allah. Nama Lazarus berarti "Allah adalah pertolonganku", dan ia tidak pernah melepaskan imannya kepada Allah. Ia mati dan segera diangkat ke Firdaus bersama Abraham (ayat 22; Lih. 23:43; Kis. 7:59; 2 Kor. 5:8; Flp. 1:23). Akhir riwayat kedua orang itu tidak dapat diubah lagi pada saat kematian (ayat 24-26). ${ }^{30}$

Berdasarkan ayat diatas sungguh jelas bahwa antara manusia yang telah meninggal dan yang masih hidup tidak bisa lagi berkomunikasi, ketika orang kaya itu meminta kepada Abraham supaya Lazarus atau salah satu dari orang mati untuk pergi ketempat saudarasaudaranya, Lazarus tidak di ijinkan untuk keluar dari tempatnya kedunia orang hidup. Menurut Derek Prime, "Kerajaan maut adalah tempat hukuman yang kekal, dan tempat pembuangan jauh dari hadirat Allah. Itulah nanti tempat semua orang yang tidak mengacuhkan Allah dan tidak menaati Injil Kristus". ${ }^{31}$

Jadi menjadi jelas pula bahwa pandangan dan kepercayaan orang-orang Pamona tentang kehidupan manusia setelah kematian adalah tidak benar jika dipandang dari sudut Firman Tuhan atau Alkitab. Ketika manusia meninggal tidak mungkin lagi ia atau rohnya atau apapun bentuknya berada di dunia ini, melainkan ketika seorang manusia meninggal tubuhnya akan kembali ke tanah dan menjadi debu tetapi jiwa dan rohnya akan langsung

\footnotetext{
${ }^{25}$ Ray Summers, Di Balik Kubur. (Bandung: Lembaga Literatur Baptis. 1994), 47.

${ }^{26}$ Pondsius Takaliuang, Antara Kuasa Gelap Dan Kuasa Terang (Malang: Yayasan Persekutuan Pekabaran Injil, 1980), 14

${ }^{27}$ Ibid.

${ }^{28}$ Ibid.

${ }^{29}$ Alkitab Terjemahan Baru. (Jakarta: Lembaga Alkitab Indonesia, 2001), 96

${ }^{30}$ Alkitab Penuntun Hidup Berkemenangan. (Jakarta: Lembaga Alkitab Indonesia, 2000), 1669

${ }^{31}$ Derek Prime, Tanya Jawab Tentang Iman Kristen. (Jakarta: Yayasan Komunikasih Bina Kasih/OMF, 2001) 191
} 
kembali kepada Tuhan dan tidak bisa lagi untuk berhubungan dengan manusia yang masih hidup di dunia.

Jika dalam Perjanjian Lama kita menemukan sebuah kesimpulan yang tegas mengenai pemanggilan arwah orang mati, maka demikian juga dalam Perjanjian Baru. Tidak ada satupun ayat yang menjelaskan bahwa praktek pemanggilan arwah bagi orang Kristen adalah benar adanya. Perjanjian Baru dengan tegas menjelaskan bahwa tidak mungkin orang yang sudah mati bisa berhubungan dengan orang masih hidup.

\section{Pemanggilan Arwah Orang Mati adalah Dosa}

Budaya adalah warisan nenek moyang yang seharusnya dijaga dan dilestarikan oleh setiap anak cucu dari generasi ke generasi. Melestarikan budaya juga merupakan wujud penghormatan dan rasa cinta setiap manusia kepada suku dari mana manusia itu berasal. Namun bagimana jika budaya dan kebiasaan yang diwariskan oleh nenek moyang itu adalah budaya yang bertentangan dengan Firman Tuhan atau Alkitab. Sebagai orang Kristen, apakah kita harus terus menjaga dan melestarikan budaya itu ataukah kita harus meninggalkannya, jika hal itu betul-betul bertentangan dengan Firman Tuhan.

Menurut Sherwood G. Lingenfelter dan Marvin K. Mayers, "Budaya yang dimiliki bersama, sangat besar artinya bagi kita. Karenanya, kita mampu merencanakan karier dengan harapan kita sungguh bisa melaksanakan apa yang kita impikan. Kita bisa membangun sebuah keluarga dan persahabatan, serta memenuhi kewajiban kita satu sama lain. Ketika kita menghadapi konflik dengan orang lain, standar dan prosedur dari budaya yang dimiliki bersama menyediakan mekanisme untuk menyelesaikan pertiakian-pertikaian itu. Dan meskipun penyelesaiannya tidak selalu memuaskan, prosesnya sudah kita kenal dan dapat diprediksi". ${ }^{32}$

Memang tidaklah mudah untuk menghilangkan budaya dari kehidupan suatu masyarakat sekalipun budaya itu bertentangan dengan ajaran agama apalagi jika jika budaya itu sangat mempengaruhi system kehidupan dari masyarakat itu sendiri. Menurut Rachmat Subagya, "Semua syarat untuk menggolongkan budaya sebagai agama terpenuhi: terdapat iman kepada Hakikat Tertinggi, manusia merasa bergantung kepada-Nya, membina sikap batin untuk bersatu kebudayaan. Kebudayaan tidak berdimensi transenden. Akan tetapi, karena alasan politik hubungan antara kebatinan dan agama dirasa begitu peka, sehingga para ahli kebatinan amat waspada dalam merumuskan hubungan antara kebatinan dan agama yang resmi. ${ }^{33}$ Itulah sebabnya mengapa budaya budaya kadangkala sulit untuk dihilangkan dari kebiasaan orang-orang yang menjalankannya, karena ternyata kadangkala sulit untuk memberi pemisahan yang jelas antara budaya itu sendiri dengan agama.

Ada hal yang menarik dengan apa yang dikatakan oleh Ronald $H$. Nash tentang sulitnya meyakinkan orang yang meyakini senuah bahwa hanya iman kepada Tuhan Yesuslah yang sungguh-sungguh benar dan keyakinan mereka adalah sesuatu yang tidak masuk akal dan bahkan merupakan tipu muslihat Iblis, "Kita semua pasti memiliki ide mula-mula tentang apa yang dimaksud dengan rasional dan tidak rasional (irrasional). Kita percaya adalah baik bila keyakinan seseorang itu rasiona; sebaliknya kita juga akan mulai memperhatikan jika keyakinan tersebut terlihat tidak rasional. Setiap orang Kristen pasti akan berpikir bahwa ia sedang bertindak secara rasional ketika ia menyatakan keyakinannya kepada Allah. Dan setiap penganut naturalisme akan meyakinkan orang Kristen tersebut bahwa ia tidak sedang bertindak rasional." ${ }^{34}$

\section{P E N U T U P}

Setelah membahas dengan panjang lebar tentang budaya pemanggilan arwah orang mati atau mompikasi pada suku Pamona serta bagaimana sebenarnya pandangan Alkitab tentang budaya itu mulai dari bab I hingga bab IV, maka pada bab ini merupakan bab penutup, dimana penulis memberikan kesimpulan serta saran-saran yang tentunya dapat bermanfaat bagi rekan-rekan hamba Tuhan yang melayani di suku Pamona, bagi orang-orang Pamona sendiri serta bermanfaat bagi semua pembaca tulisan ini.

\section{Kesimpulan}

Pertama, seperti suku-suku lainnya di Indonesia, demikian pula dengan suku Pamona memiliki banyak budaya yang sangat menarik untuk di pelajari. Karena dari banyaknya

\footnotetext{
${ }^{32}$ Sherwood G. Lingenfelter dan Marvin K. Mayers, Menggeluti Misi Lintas-Budaya, (Jakarta: Yayasan Komunikasi Bina Kasih, 2008), 19.

${ }_{33}$ Rachmat Subagya, Agama Asli Indonesia (Jakarta: Sinar Harapan dan Yayasan Cipta Loka Caraka, 1981), 269

${ }^{34}$ Ronald H. Nash, Iman Dan Akal Budi (Surabaya: Momentum, 2004), 105
} 
budaya yang ada memiliki makna positif yang tentunya memiliki manfaat positif pula bagi kelangsungan kehidupan suku Pamona dimasa yang akan datang.

Kedua, kehidupan suku Pamona sangat sulit untuk dipisahkan dengan budaya mereka, termasuk budaya pemanggilan arwah orang mati atau yang dikenal dengan istilah mompikasi. Mengapa demikian? Karena budaya itu telah berakar sekian lama secara turun temurun dari generasi ke generasi pada orang-orang Pamona.

Ketiga, bagi orang Pamona menghargai orang yang telah mati adalah sebuah kewajiban mutlak yang harus dilakukan, karena bagi suku Pamona orang mati dapat memberi berkat, memelihara serta memberi umur panjang. Namun sebaliknya, orang-orang Pamona meyakini bahwa orang mati juga dapat mendatangkan malapetaka dan kutukan bagi mereka yang tidak menghargai arwah orang mati itu.

Ketiga, sungguh tragis, di dunia yang modern seperti sekarang ini, kehidupan seharihari orang-orang Pamona masih mempercayai manifestasi-manifestasi orang mati yang tentunya hanya merupakan tipu muslihat Iblis untuk memperdaya dan membuat orangorang percaya tetap tinggal di dalam dosa.

Keempat, tidak ada satupun ayat atau bagian dalam kitab Perjanjian Lama dan Perjanjian Baru yang memberikan indikasi bahwa manusia yang telah mati dapat menjalin hubungan dengan orang yang masih hidup. Dalam kitab Perjanjian Lama dan Perjanjian Baru juga tidak ditemukan ada bagian dimana Allah mengisinkan manusia yang masih hidup untuk berhubungan dengan orang yang telah mati.

Kelima, menurut Firman Tuhan, berhubungan dengan dengan orang mati adalah dosa. Itulah sebabnya dapat disimpulkan pula bahwa budaya pemanggilan arwah pada suku Pamona adalah dosa dihadapan Tuhan. Untuk itu, budaya itu tidak boleh dipelihara tetapi harus ditinggalkan agar orang-orang Pamona yang telah menjadi orang-orang percaya dapat bertunbuh dalam iman dan hidup sesuai dengan Firman Tuhan.

\section{Saran-Saran}

Sebagai seorang suku Pamona, penulis menyadari bahwa tidaklah mudah untuk menghilangkan budaya mompikasi pada suku Pamona. Namun jika deberi penjelasan dan pemahaman yang jelas kepada orang-orang Pamona maka tentunya mereka pasti akan mengerti dan akhirnya meniggalkan budaya itu. Untuk itulah demi tercapainya tujuan penulisan ini, maka penulis memberikan saran-saran sebagai berikut:

Pertama, orang-orang Pamona harus menyadari bahwa ada banyak budaya yang perlu dilestarikan pada suku Pamona, namun suku Pamona juga perlu menyadari bahwa dari sekian banyak budaya itu ada yang bertentangan dengan Firman Tuhan dan salah satunya adalah budaya pemanggilan arwah orang mati atau mompikasi.

Kedua, orang-orang Pamona harus menyadari bahwa Alkitab atau Firman Tuhan harus menjadi pedoman dasar bagi kehidupan mereka sehari-hari. Orang-orang Pamona harus menyadari bahwa sumber segala berkat dan damai sejahtera adalah hanya Tuhan Yesus yang adalah Tuhan pencipta langit dan bumi, yang menentukan mati dan hidupnya manusia.

Ketiga, Gereja harus memiliki sikap yang tegas dan berani dalam memberikan penjelasan kepada jemaatnya sehubungan dengan hal-hal yang menjadi kebiasaan atau budaya yang ada pada jemaatnya. Jika hal itu adalah salah atau dosa, maka gereja harus berani dan tegas untuk menyatakan bahwa itu adalah dosa.

Keempat, tidak dapat disangkali bahwa hamba-hamba Tuhan atau pelayan-pelayan Tuhan, khususnya yang melayani pada suku Pamona memiliki tangungg jawab yang sangat berat. Untuk itulah penulis menyarankan agar rekan-rekan hamba Tuhan yang melayani pada suku Pamona memiliki pemahaman yang jelas dan kuat terhadapt Firman Tuhan, agar apa yang disampaikan dapat diterima dengan baik oleh jemaat yang dilayani.

Kelima, kepada semua hamba-hamba Tuhan hendaknya terus belajar dan memperkaya diri dengan pengetahuan teologi serta hidup sesuai dengan Firman Tuhan agar hidupnya dipenuhi oleh Roh Kudus sehingga ketika hamba-hamba Tuhan itu berdiri di mimbar dan menyampaikan Firman Tuhan semua umat Tuhan dapat menerima dan mau melakukan sesuai dengan apa yang di dengarnya. 


\section{KEPUSTAKAAN}

Alkitab

Alkitab, Jakarta: Lembaga Alkitab Indonesia, 2005.

Alkitab Bahasa Indonesia Sehari-hari. Jakarta: Lembaga Alkitab Indonesia, 1995.

Alkitab Penuntun Hidup Berkelimpahan. Jakarta: Lembaga Alkitab Indonesia, 2000

Kamus.

Kamus Umum Bahasa Indonesia. Badudu, J.S. dan Sutan Muhammad Zain. Kamus Umum Bahasa Indonesia. Jakarta, 1994.

Kamus Besar Bahasa Indonesia. Pusat Bahasa Departemen Pendidikan Nasional. Jakarta, 2001.

Kamus Wikipedia: Ensiklopedia Bebas Berbahasa Indonesia.

\section{Buku-Buku}

Epp H. Theodore. Bagaimana Caranya Melawan Setan, Mimery Press.

Octavianus P. Identitas Kebudayaan Asia Dalam Terang Firman Allah, Malang: Yayasan Persekutuan Pekabaran Injil Indonesia, 1985.

Sproul R.C. Kebenaran-Kebenaran Dasar Iman Kristen, Malang: Departemen Literatur SAAT, 2000.

Orr, William W. Setan Ada Atau Tidak?, Bandung: Kalam Hidup, 1970.

MacMillan A. John. Perjuangan Melawan Kuasa Kegelapan, Malang: Gandum Mas, 1985.

E.P. Gintings, Djorelit Surbakti dan Maria Br. Ginting, OKULTISME, Bandung: Bintang Media Informasi, 2007.

Gobay M. John, Praktek \& Strategi Iblis, Bandung: Yayasan Kalam Hidup, 1996.

Seri Institut Gereja Toraja-SITGT. Roh-Roh \& Kuasa-Kuasa Gaib.

Subagya Rachmat. Agama Asli Indonesia, Jakarta: Sinar Harapan dan Yayasan Cipta Loka Caraka, 1981.

T Neil Anderson. Bebas Dari Kuasa Gelap, Yogyakarta: Yayasan ANDI, 1996.

Nash H Ronald. Iman dan Akal Budi, Surabaya: Momentum, 2004.

Scheunemann Volkhrad. Apa Kata Alkitab Tentang Dunia Orang Mati, Malang: Yayasan Pekabaran Injil Indonesia, 1983.

Sihombing Justin. Jangan Diperdaya, Jakarta: BPK Gunung Mulia, 1983.

Takaliuang Pondsius. Antara Kuasa Gelap dan Kuasa Terang, Malang: Yayasan Persekutuan Pekabaran Injil, 1980.

Cerullo Morris. Strategi Peperangan Rohani, Bandung: GSN Indonesia, 1994.

Prime Derek. Tanya Jawab Tentang Iman Kristen, Jakarta: Yayasan Komunikasih Bina Kasih/OMF, 2001.

Lea Larry. Senjata Peperangan Anda, Jakarta: YPI Imanuel, 1999.

M.D. JR. Moody A. Raymond. Hidup Sesudah Mati, Jakarta: Gramedia, 1987.

Graham Billy. Menghadapi Kematian dan Kehidupan Sesudahnya, Bandung: Lembaga Literatur Baptis, 2001.

Philip, S, Mc. Candlish. Dunia Roh, Bandung: Kalam Hidup, 1979.

Wiebe Warren W. Strategi Setan, Yogyakarta: Yayasan Andi, 1992.

Hunt Gladys. Pandangan Kristen Tentang Kematian, Jakarta: BPK Gunung Mulia, 1987.

Summers Ray. Di Balik Kubur, Bandung: Lembaga Literatur Baptis, 1994.

Soekahar H. Satanisme Dalam Pelayanan Pastoral, Malang: Gandum Mas, 1986.

Larson Bob. Membongkar Tipu Daya Iblis, Yogyakarta: Yayasan ANDI, 1990.

Jeffrey R. Grant. Perjalanan Menuju Kekekalan, Jakarta: Yayasan Pekabaran Injil Immanuel, 1994.

Waqner Pieter C. Roh-Roh Teritorial, Jakarta: Yayasan Pekabaran Injil Immanuel, 1994.

Lingenfelter G. Sherwood dan Mayers K. Marvin. Menggeluti Misi Lintas Budaya, Jakarta: Yayasan Komunikasih Bina Kasih, 2008

\section{Wawancara}

Marten Tarumidi, Wawancara Dengan Penulis. Mangkutan, 11 Maret 2010.

Calvin Lakipundu, Wawancara Dengan Penulis. Mangkutana, 12 Maret 2010.

Sarii Tago'a, Wawancara Dengan Penulis. Mangkutana, 13 Maret 2010.

Maneci Mangile, Wawancara Dengan Penulis. Mangkutana, 13 Maret 2010.

Saidman Koleba Tago'a, Wawancara Dengan Penulis. Mangkutana, 14 Maret 2010.

Pabindu, Wawancara Dengan Penulis. Mangkutana, 05 April 2010. 